\title{
Study of Genetic Diversity for Yield and Yield Contributing Traits in Black Gram (Vigna mungo L.)
}

\author{
Deeksha Chandrakar*, Abhinav Sao and Deepak Gauraha
}

Department of Genetics and Plant Breeding, College of Agriculture, Indira Gandhi Krishi Vishwavidyalaya, Raipur-492012 (Chhattisgarh), India

*Corresponding author

\section{A B S T R A C T}

\begin{tabular}{l} 
K e y w o r d s \\
$\begin{array}{l}\text { Black gram, } \\
\text { Genetic diversity, } \\
\text { Cluster analysis }\end{array}$ \\
Article Info \\
$\begin{array}{l}\text { Accepted: } \\
20 \text { June } 2020 \\
\text { Available Online: } \\
10 \text { July } 2020\end{array}$ \\
\hline
\end{tabular}

\section{Introduction}

Black gram $(2 \mathrm{n}=22)$, originated in India and Vigna mungo L. Hepper is the scientific name of black gram. Vigna mungo var. silvestris is considered as progenitor of black gram which grows wild in India. It is most popular pulse and can be most appropriately referred to as the king of the pulses due to its mouth watering taste and a lot of nutritional qualities. It is also largely used in South Indian culinary preparations. Black gram is one of the key ingredient in South Indian dishes such as idli and dosa. It is used in preparation of dal makhini and is very popular in Punjabi cuisine. It is used in preparation of dal in Bengal. It is an important ingredient of dal which is usually consumed with bati in Rajasthan. Black gram contain amino acids, vitamins, fat (1.5), carbohydrates $(60 \%)$ and protein $(25-26 \%)$. It is rich source of Vitamin $\mathrm{A}, \mathrm{B}_{1}, \mathrm{~B}_{3 \mathrm{a}}$ and it contain small amount of niacin, riboflavin, thiamine and vitamin $\mathrm{C}$ in it. It followed soybean in dietary protein content. Dry seed of black gram are good source of phosphorus. Genetic diversity is an essential pre-requisite in selecting parents for hybridization and generating high yielding genotypes in any crop breeding programme. Genetic diversity play a valuable role in plant breeding, because crossing between lines of divergent origin, give more diverse progenies than closely related parents. 


\section{Materials and Methods}

The experiment was conducted in MULLaRP Experimental Field, Research cum Instructional Farm, Indira Gandhi Krishi Vishwavidalaya, Raipur, Chhattisgarh, India. The experiment was conducted in randomized block design with two replications.

The material was sown on $19^{\text {th }}$ July, 2018. The seed was dibbed at $30 \mathrm{~cm}$ distance between row to row and $10 \mathrm{~cm}$ distance between plant to plant. Observations were recorded on five randomly selected plants from each treatment in each replication.

The representative bulk sample from each entry in each replication were used for analysis of protein content. Mean value of 5 plants were used for statistical analysis. Observation were recorded for 13 yield related characters such as days to $50 \%$ flowering, days to maturity, plant height, number of primary branches per plant, number of secondary branches per plants, pod length, number of pods per plant, number of seeds per pod, 100-seed weight, biological yield per plant, harvest index, protein content and seed yield per plant, respectively.

\section{Results and Discussion}

Genetic diversity analysis was estimated through cluster analysis. All the 62 genotypes were grouped into five clusters as shown in Table 1 . The cluster -II had maximum number of mutant lines (32) followed by cluster $-\mathrm{I}$ (27), cluster -III (1), cluster- IV (1) and cluster $-\mathrm{V}(1)$.

The maximum cluster mean for days to $50 \%$ flowering was obtained cluster V (74.00) and minimum in cluster IV (62.50). The cluster mean for days to maturity was higher for cluster I (118.29) whereas, the lowest mean value exhibited in cluster IV (111.00). For plant height, the maximum cluster mean value was exhibited for cluster IV (71.25) and minimum in cluster $\mathrm{V}$ (52.30). The highest cluster mean for primary branches per plant was obtained cluster III (7.25) whereas, lowest value was exhibited for cluster $\mathrm{V}$ (1.83). The maximum cluster mean recorded for secondary branches per plant was obtained cluster IV (9.35) whereas, the lowest value was exhibited for cluster III (3.75). The highest cluster mean for pods per plant was obtained cluster IV (16.80) and lowest in cluster V (7.80).

Table.1 Characteristics of black gram mutant line in cluster

\begin{tabular}{|c|c|c|c|c|}
\hline S. No. & Cluster no. & $\begin{array}{l}\text { No. Of mutant line in each } \\
\text { cluster }\end{array}$ & $\begin{array}{l}\text { \% of } \\
\text { line }\end{array}$ & Prominent trait \\
\hline 1 & I & 27 & 43.54 & $\begin{array}{l}\text { Days to } 50 \% \text { flowering, days to } \\
\text { maturity. }\end{array}$ \\
\hline 2 & II & 32 & 51.61 & \\
\hline 3 & III & & 1.61 & $\begin{array}{l}\text { Primary branches per plant, } \\
\text { seed per pod, protein content }\end{array}$ \\
\hline 4 & IV & 1 & 1.61 & $\begin{array}{l}\text { Plant height, secondary } \\
\text { branches per plant, pod per } \\
\text { plant, 100 seed weight, } \\
\text { biological yield, seed yield per } \\
\text { plant, }\end{array}$ \\
\hline 5 & V & 1 & 1.61 & Harvest index \\
\hline
\end{tabular}


Table.2 Cluster means for the characters under study in black gram

\begin{tabular}{|l|c|c|c|c|c|}
\hline \multicolumn{1}{|c|}{ Cluster } & I & II & III & IV & V \\
\hline Days to 50\% flowering & 73.59 & 69.91 & 66.5 & 62.5 & 74 \\
\hline Days to maturity & 118.30 & 115.14 & 117 & 111 & 118 \\
\hline Plant height & 61.95 & 60.99 & 65 & 71.25 & 52.3 \\
\hline $\begin{array}{l}\text { Number of primary } \\
\text { branches per plant }\end{array}$ & 3.20 & 4.34 & 7.25 & 6.75 & 1.83 \\
\hline $\begin{array}{l}\text { Number of secondary } \\
\text { branches per plant }\end{array}$ & 5.22 & 7.32 & 3.75 & 9.35 & 3.3 \\
\hline Number of pods per plant & 10.46 & 12.72 & 14.75 & 16.8 & 7.8 \\
\hline Pod length & 6.03 & 6.11 & 4.80 & 8.05 & 6.28 \\
\hline Number of seeds per pod & 8.24 & 8.93 & 9.5 & 7.85 & 8.05 \\
\hline 100 seed weight & 6.53 & 6.26 & 6.2 & 6.75 & 6.35 \\
\hline Biological yield & 12.11 & 12.32 & 13.35 & 14.5 & 5.22 \\
\hline Harvest index & 35.40 & 41.62 & 30.79 & 48.65 & 98.02 \\
\hline Protein content & 34.96 & 36.36 & 38.61 & 37.6 & 36.54 \\
\hline Seed yield per plant & 3.09 & 3.14 & 2.64 & 4.63 & 2.07 \\
\hline
\end{tabular}

Table.3 List of top mutant lines on the basis of yield

\begin{tabular}{|c|c|c|}
\hline S.No. & Name of lines & Yield (g /plant) \\
\hline $\mathbf{1}$ & IU450-3 & 4.57 \\
\hline $\mathbf{2}$ & KU500-2 & 4.42 \\
\hline $\mathbf{3}$ & KU450-10 & 4.17 \\
\hline $\mathbf{4}$ & IU450-4 & 3.95 \\
\hline $\mathbf{5}$ & KU96-3 & 3.88 \\
\hline $\mathbf{6}$ & IU400-1 & 3.35 \\
\hline $\mathbf{7}$ & KU400-4 & 3.4 \\
\hline $\mathbf{8}$ & IU450-1 & 2.95 \\
\hline $\mathbf{9}$ & KU400-3 & 2.89 \\
\hline $\mathbf{1 0}$ & KU500-3 & 2.87 \\
\hline
\end{tabular}

Table.4 Distances between cluster centroids (intra and inter-cluster $\mathrm{D}^{2}$ value)

\begin{tabular}{|c|c|r|r|r|r|}
\hline CLUSTER & I & \multicolumn{1}{|c|}{ II } & \multicolumn{1}{c|}{ III } & \multicolumn{1}{|c|}{ IV } & \multicolumn{1}{|c|}{ V } \\
\hline I & $\mathbf{1 3 . 7 7 2}$ & 8.746 & 11.739 & 22.969 & 63.863 \\
\hline II & & $\mathbf{1 5 . 3 5 2}$ & 13.496 & 16.343 & 58.146 \\
\hline III & & & $\mathbf{0 . 0 0 0}$ & 21.585 & 69.943 \\
\hline IV & & & & $\mathbf{0 . 0 0 0}$ & 56.716 \\
\hline V & & & & & $\mathbf{0 . 0 0 0}$ \\
\hline
\end{tabular}


The maximum cluster mean value for pod length was obtained for cluster IV (8.05), whereas the lowest mean exhibited for cluster III (4.81). The maximum cluster mean for seeds per pod was obtained for cluster III (9.50), whereas the minimum value was exhibited for cluster IV (7.85). The highest cluster mean for 100-seed weight was exhibited for cluster IV (6.75) and lowest in cluster III (6.20). The highest cluster mean for biological yield was exhibited for cluster IV (14.51), whereas lowest value was exhibited for cluster $\mathrm{V}$ (5.22). The maximum cluster mean value for harvest index was reported in cluster V (98.02) and lowest in cluster III (30.79). The highest cluster mean for protein content was found in cluster III (38.61) and lowest value in cluster I (34.96).

The maximum inter cluster distance were obtained between cluster $\mathrm{V}$ and cluster III (69.94) which is followed by cluster $\mathrm{V}$ and cluster I (63.86). The minimum inter cluster value observed between cluster II and cluster I (8.74). The inter cluster value varied from a range of 69.94 to 8.74 . The finding of the study are in general agreement to the observation of Jayamani and Sathya (2013), Konda et al (2009), Krishna et al (2002), Shanti et al (2006) and Venkatesan et al (2003).

In conclusion it is clear from the above results that the cluster mean for various quantitative traits related to yield attributes revealed that different respond differentially for various traits. Cluster IV showed highest mean performance for seed yield per plant (4.63) followed by cluster V (2.07). After the evaluation of mutant lines, it was observed that IU 450-3 was top yielder followed by KU 500-2 (4.42), KU 450-10 (4.17), respectively. These lines can be further utilized in crop improvement programme.

\section{References}

Jayamani, P. and Sathya, M. 2013. Genetic diversity in pod character of blackgram (Vigna mungo (L.)Hepper). Legume Research, 36: 220-223.

Konda, C. R., Salimath, P. M. and Mishra, M. N. 2009.Genetic diversity in blackgram (Vigna mungo (L.)Hepper). Legume Research, 30 (3): 212-214.

Rajendra Kumar, Avadhesh Singh, Rathi, A.S. and Ram Krishna. 2002. Genetic divergence in relation to breeding for grain yield in urdbean (Vigna mungo (L.) Hepper). Legume Research, 25 (2): 109-112.

Shanthi, P., Jebaraj, S and Manivannan, N. 2006.Genetic diversity in urdbean (Vigna mungo L. Hepper). Legume Research, 29 (3): 181-185.

Venkatesan, M., Veeramani, N., Thangavel, P. and Ganesan, J. 2003.Genetic divergence in cowpea [Vigna unguiculata (L.)Walp]. Legume Research, 27: 223-225.

\section{How to cite this article:}

Deeksha Chandrakar, Abhinav Sao and Deepak Gauraha. 2020. Study of Genetic Diversity for Yield and Yield Contributing Traits in Black Gram (Vigna mungo L.). Int.J.Curr.Microbiol.App.Sci. 9(07): 2316-2319. doi: https://doi.org/10.20546/ijcmas.2020.907.270 